\title{
Pemeriksaan Glukosa, Kolesterol dan Asam Urat pada Masyarakat Peserta Car Free Day di Balai Pelatihan Kesehatan (Bapelkes) Kota Semarang
}

\section{Glucose, Cholesterol and Uric Acid Checks in Car Free Day Participants at Health Training Center of Semarang City}

\author{
Ana Hidayati Mukaromah ${ }^{1}$, Gela Setya Ayu Putri ${ }^{2}$, Nurul Qomariyah, Wijanarko ${ }^{3}$, \\ Pratiwi R. H. Sya'diah ${ }^{4}$ \\ S2 Sains Laboratorium Medis, Universitas Muhammadiyah Semarang, \\ Kota Semarang, Indonesia \\ 1ana hidayati@,unimus.ac.id
}

Riwayat Artikel: Dikirim 2 Januari 2020; Diterima 16 Mei 2020; Diterbitkan 20 Mei 2020

\begin{abstract}
Abstrak
Gejala suatu penyakit dapat dicegah apabila dilakukan pemeriksaan kesehatan secara rutin. Pemeriksaan kesehatan dapat dilakukan di laboratorium milik pemerintah maupun swasta, atau pemeriksaan secara gratis yang dilakukan oleh institusi pendidikan kesehatan melalui kegiatan pengabdian masyarakat. Pelaksanaan pengabdian masyarakat ini dilakukan oleh dosen dengan melibatkan mahasiswa S2 Sains Laboratorium Medis Universitas Muhammadiyah Semarang. Kegiatan pengabdian masyarakat ini dilakukan pada tanggal 15 Desember 2019 di depan Kantor Balai Pelatihan Kesehatan Semarang (BAPELKES) Jl Pahlawan Semarang ini dengan pemeriksaan kesehatan meliputi kadar glukosa, kolesterol dan asam urat. Sasaran kegiatan ini adalah masyarakat yang sedang melakukan aktivitas pada saat Car Free Day. Pemeriksaan kesehatan ini menggunakan metoda Point of Care testing (POCT). Hasil pemeriksaan kesehatan ini adalah responden perempuan cenderung mempunyai kadar kolesterol di atas normal, sedangkan responden laki-laki cenderung mempunyai kadar glukosa dan asam urat di atas normal. Kadar rata-rata kolesterol, glukosa, dan asam urat pada laki-laki berturut-turut adalah 224,2; 123,1; 4,8 mg/dL sedangkan pada perempuan berturut-turut adalah 194,5; 121,2; 6,0 mg/dL. Pada usia 12-65 tahun, kadar kolesterol rata-rata semakin meningkat dari 189,0 menjadi 217,8 mg/dL (peningkatan 15,25\%) dan kadar glukosa rata-rata meningkat dari 84,4 menjadi 131,5 $\mathrm{mg} / \mathrm{dL}$ (peningkatan 55,80\%), sedangkan kadar asam urat rata-rata menurun dari 5,4 menjadi 5,2 mg/dL (penurunan 3,85\%). Kesimpulan dari kegiatan pemeriksaan kesehatan tentang hasil kadar kolesterol, glukosa, dan asam urat dapat digunakan untuk mengecek kesehatan masyarakat.
\end{abstract}

Kata kunci: Glukosa, kolesterol, asam urat, dan pemeriksaan kesehatan

\begin{abstract}
Symptoms of a disease can be prevented if routine health checks are done. Health checks can be carried out in public and private laboratories, or free checks conducted by health education institutions through community service activities. The implementation of community service is carried out by lecturers involving students of the Medical Laboratory Science at the Mubammadiyah University of Semarang. This community service activity was carried out on December 15, 2019 in front of the Semarang Health Training Center Office on December 15, 2019. The inspection method uses Point of Care testing (POCT). The results of the examination that the number of respondents with cholesterol levels above normal for women more than men, while glucose and uric acid levels above normal in men more than women. The average cholesterol, glucose, and uric acid levels for men were 224.2; 123.1; $4.8 \mathrm{mg} / \mathrm{dL}$ respectively, while for women is $194.5 ; 121.2 ; 6,0 \mathrm{mg} / \mathrm{dL}$. The bigher age (12 - 65 years), the average cholesterol level increases from 189 to $217.8 \mathrm{mg} / \mathrm{dL}(15.25 \%)$ and the average glucose level increase from 84.4 to $131.5 \mathrm{mg} /$ $d \mathrm{~L}(55.80 \%)$, while the average uric acid level decreases from 5.4 to $5.2 \mathrm{mg} / \mathrm{dL}(3.85 \%)$. The conclusions of the health inspection activity about the result of cholesterol, glucose, and uric acid levels can be used to check public health
\end{abstract}

Keywords: Glucose, cholesterol, gout, and health check. 


\section{PENDAHULUAN}

Kematian yang disebabkan penyakit Diabetes melitus (DM) merupakan urutan ke-6 di dunia dan prevalensinya terus meningkat (Departemen Kesehatan, 2013) dan tahun 2015 terdapat 415 juta orang dewasa menderita DM (International Diabetes Federation, 2015). DM merupakan penyakit metabolik dengan hiperglikemia kronik yang disebabkan oleh metabolisme karbohidrat, lemak, dan protein yang kurang baik. Hiperglikemia diakibatkan oleh kerusakan sekresi atau terganggunya kerja hormon insulin. DM yang tidak terkontrol dapat menyebabkan kegagalan berbagai organ dan jaringan seperti mata, ginjal, saraf, jantung, dan pembuluh darah (World Health Organization, 2016).

Macam-macam tipe penyakit DM antara lain DM tipe I dan DM tipe 2. DM tipe I disebabkan sel-sel mengalami kerusakan sehingga pankreas dalam memproduksi insulin terhambat dan metabolisme gula dalam darah menjadi terganggu sehingga tubuh memerlukan tambahan insulin dari luar. DM tipe II disebabkan bukan karena pengaruh hormon insulin namun karena gaya hidup yang menyebabkan penggunaan insulin tidak efektif sehingga tubuh kurang bergerak yang berakibat obesitas (gemuk berlebihan) (Sartika dkk., 2013). DM tipe 2 ini sering tidak terdeteksi, sehingga penderita terdiagnosis DM setelah komplikasi terjadi (World Health Organization, 2016).

Asam urat merupakan produk atau hasil akhir dari metabolisme purin dan berbentuk kristal dan. Purin merupakan salah satu komponen asam nukleat yang terdapat didalam inti sel tubuh. Sumber Purin ada 2 macam yaitu tanaman seperti sayur, buah, kacang-kacangan dan hewan seperti udang, cumi, kepiting, jeroan dan lain-lain (Andry, 2009). Sintesis asam urat dilakukan dalam hati kemudian dialirkan ke ginjal oleh darah untuk difiltrasi, direabsorpsi sebagian dan diseksresikan sebagian sebelum dieksresikan melalui urine (Andry, 2009).

Kadar asam urat yang normal kurang dari $7 \mathrm{mg} / \mathrm{dL}$, pada wanita yang belum monopause kadar asam uratnya di bawah $7 \mathrm{mg} / \mathrm{dL}$ disebabkan hormon estrogen yang dalam darah masih tinggi, sehingga dapat mengeluarkan asam urat melalui ginjal, sedangkan wanita yang sudah monopause maka kadar hormon estrogen meningkat, sehingga kadar asam uratnya melebihi $7 \mathrm{mg} / \mathrm{dl}$ (Kertia Nyoman, 2009). Penderita DM tipe II bila tidak menjaga pola makannya, maka kadar asam uratnya juga akan meningkat.

Kolesterol adalah lemak berwarna kekuningan yang diproduksi oleh tubuh terutama di dalam hati. Tubuh menggunakan kolesterol untuk membuat garam empedu yang membantu usus menyerap lemak. Fungsi kolesterol adalah sebagai zat esensial untuk membran sel tubuh, bahan pokok pembentukan garam empedu yang sangat diperlukan untuk pencernaan makanan, dan bahan baku untuk pembentukan hormon steroid, misalnya progesterone (Murray, 2009; Graha, 2010).

Kolesterol baik adalah lipoprotein dengan kandungan protein tinggi dan memiliki sedikit lemak yang dikenal dengan High Density Lipoprotein (HDL). HDL mengandung molekul anti oksidan yang dapat mencegah perubahan Low Density Lipoprotein (LDL) menjadi lipoprotein yang cenderung menyebabkan penyakit jantung (Widodo, 2016; Nurhidajah et al, 2019). HDL berfunfsi mencegah terjadinya penyimpanan lemak di dalam pembuluh darah, mengumpulkan kolesterol dari darah dan daerah yang terpengaruh ateriosklerosis dan membantu pembalikan proses sehingga dapat mencegah thrombosis (Tisnadjaja, 2006; Graha, 2010).

Bahan makanan yang mempengaruhi kadar HDL adalah asupan serat, dan gorengan. Asupan serat larut (soluble fiber) terdapat pada buah-buahan, 
sayuran, kacang-kacangan, biji-bijian, bulir utuh, dan oats dapat membantu menaikkan HDL darah. Minyak jelantah memiliki ikatan asam lemak jenuh dan selama proses menggoreng, minyak akan mengalami perubahan komposisi asam lemak serta kualitas minyak (Nurhidajah et al, 2019). Ikatan asam lemak ini sulit diurai oleh tubuh dan terbawa dalam aliran darah dan akan mengendap pada pembuluh darah di jantung dan menyumbat aliran darah, sehingga dapat mengakibatkan peningkatan kadar kolesterol total, LDL (kolesterol jahat) dan trigliserida, serta penurunan kadar HDL (kolesterol baik) dalam darah (Tisnadjaja, 2006; Graha, 2010).

Tingkat derajat kesehatan masyarakat dapat ditingkatkan diantaranya dengan adanya kegiatan pemeriksaan kesehatan yang dilakukan oleh mahasiswa prodi S2 Sains Laboratorium Medis Universitas Muhammadiyah Semarang pada tanggal 15 Desember 2019 di depan gedung BAPELKES Jl. Pahlawan Semarang sebagai tempat kegiatan atau aktivitas masyarakat pada Car Free Day setiap hari Minggu. Lokasi ini merupakan tempat masyarakat melakukan jalan sehat, senam, dan rekreasi kuliner, yang memungkinkan sekali untuk diadakan pemeriksaan kesehatan secara langsung yaitu pemeriksaan glukosa, asam urat, dan kolesterol.

\section{METODE}

Metode pemeriksaan kesehatan digunakan metode Point Of Care Testing (POCT). Waktu pengabdian kepada masyarakat pada tanggal 15 Desember 2019 di dan tempat pengabdian adalah di depan gedung BAPELKES Jl. Pahlawan Semarang Sampel berupa darah responden yang berjumlah 117 masing-masing diambil darah kapiler beberapa tetes sesuai kebutuhan pemeriksaan.

Kegiatan pemeriksaan kesehatan ini menggunakan alat lancet, alkohol swab, kapas, bolpoin, stick GCU (Glucosa, Cholesterol, Uric acid) Easy Touch auto click, dan kertas hasil. Bahan pengabdian kepada masyarakat adalah darah kapiler responden.

Teknik pengumpulan data adalah data primer dari hasil pemeriksaan kadar glukosa, asam urat, dan kolesterol. Selanjutnya data tersebut dianalisis secara deskriptif sesuai jenis kelamin dan usia dengan kategori data terendah dan tertinggi untuk setiap pemeriksaan kadar glukosa, kolesterol, asam urat dan ditabulasikan ke dalam Tabel.

\section{HASIL DAN PEMBAHASAN}

Data hasil pemeriksaan kesehatan tanggal 15 Desember 2019 di depan gedung BAPELKES Jl. Pahlawan Semarang sebanyak 117 responden dikelompokkan berdasarkan jumlah responden yang mempunyai kadar kolesterol, glukosa, dan asam urat yang hasilnya normal, di atas normal dan berdasarkan jenis kelamin tertera pada Gambar 1.

Grafik 1.

Grafik jumlah responden yang mempunyai kadar kolesterol, glukosa, dan asam urat ( $\mathrm{mg} / \mathrm{dL})$ dengan hasil normal dan di atas normal dan berdasarkan jenis kelamin

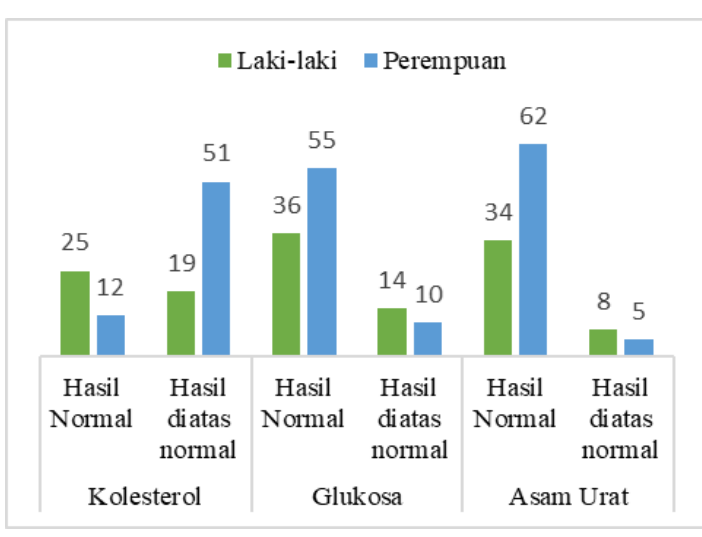

Grafik 1 menunjukkan bahwa bahwa kadar kolesterol di atas normal pada responden laki-laki lebih banyak dibandingkan perempuan, sedangkan kadar glukosa dan asam urat di atas normal pada perempuan lebih banyak dibandingkan dengan laki-laki. Hal ini disebabkan karena sebagian besar laki-laki senang beraktivitas 
dan berolahraga yang dapat mengubah glukosa menjadi energi, sehingga kadar glukosa menjadi lebih rendah. Selanjutnya kadar kolesterol, glukosa, dan asam urat berdasarkan jenis kelamin tertera pada Grafik 2.

\section{Grafik 2.}

Grafik kadar rata-rata kolesterol, glukosa, dan asam urat $(\mathrm{mg} / \mathrm{dL})$ berdasarkan jenis kelamin

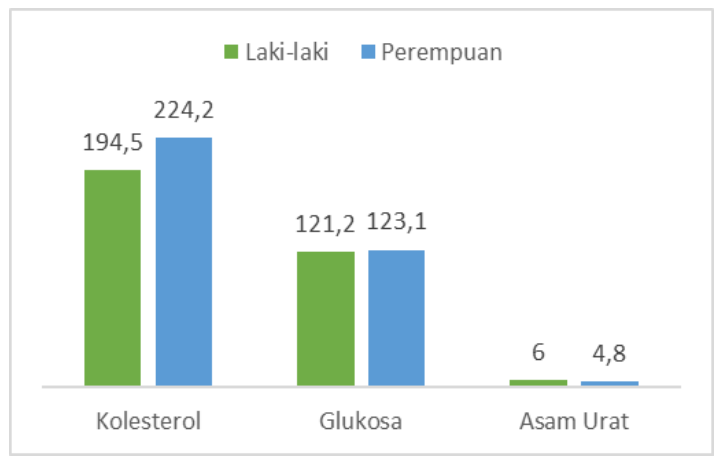

Grafik 2 menunjukkan rata-rata kadar glukosa dan kolesterol pada laki-laki lebih rendah daripada perempuan. Hal ini disebabkan karena sebagian besar laki-laki senang beraktivitas dan berolahraga yang dapat mengubah glukosa menjadi energi, sehingga kadar glukosa dan kolesterol menjadi lebih rendah. Kadar asam urat lakilaki lebih tinggi daripada perempuan, namun masih dalam kadar normal. Selanjutnya pengelompokan kadar kolesterol, glukosa, dan asam urat berdasarkan usia tertera pada Tabel 1 .

Tabel 1:

Kadar Kolesterol, Glukosa, dan Asam Urat pemeriksaan berdasarkan usia.

\begin{tabular}{|c|c|c|c|}
\hline $\begin{array}{c}\text { Usia } \\
\text { (Tahun) }\end{array}$ & $\begin{array}{c}\text { Kolesterol } \\
(\mathrm{mg} / \mathrm{dL})\end{array}$ & $\begin{array}{c}\text { Glukosa } \\
(\mathrm{mg} / \mathrm{dL})\end{array}$ & $\begin{array}{c}\text { Asam } \\
\text { Urat } \\
(\mathrm{mg} / \mathrm{dL})\end{array}$ \\
\hline $12-25$ & 189,0 & 84,4 & 5,4 \\
\hline $26-45$ & 207,4 & 105,1 & 5,3 \\
\hline $46-65$ & 217,8 & 131,5 & $5,2 \mathrm{~K}$ \\
\hline
\end{tabular}

Berdasarkan Tabel 1, kadar kolesterol, glukosa, dan asam urat yang dikelompokkan berdasarkan usia terdapat hasil bahwa semakin tinggi usia maka kadar kolesterol dan glukosa semakin meningkat yaitu kadar kolesterol dari 189 menjadi $217,8 \mathrm{mg} / \mathrm{dL}$ dan kadar glukosa dari 84,4 menjadi $131,5 \mathrm{mg} / \mathrm{dL}$, sedangkan kadar asam urat cenderung menurun dari 5,4 menjadi $5,2 \mathrm{mg} / \mathrm{dL}$. Hal ini sesuai dengan hasil penelitian Sartika dkk. (2009) tentang hubungan pola makan dengan penyakit DM tipe 2, semakin usia bertambah maka aktivitas perempuan semakin berkurang dan pola makan tidak sehat dan tidak teratur, sedangkan aktivitas olah raga pada laki-laki lebih tinggi daripada perempuan. Dokumentasi pelaksanaan pengabdian masyarakat tertera pada Gambar 1 dan Gambar 2.

Gambar 1:

Dokumentasi Pengabmas
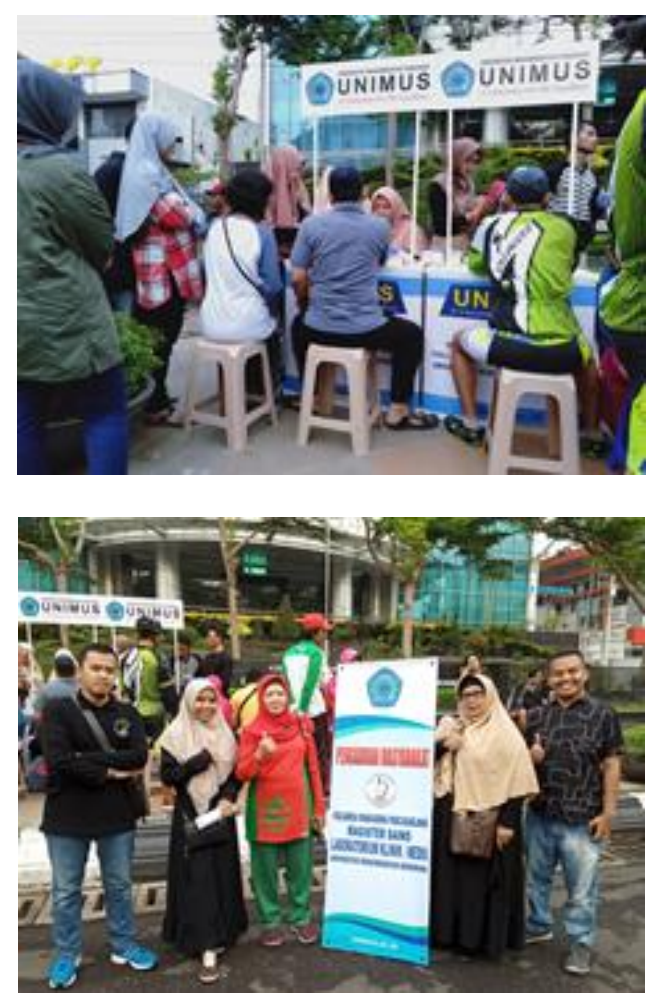

Sumber: Dokumentasi Pribadi 
Gambar 2:

Dokumentasi Pengabmas
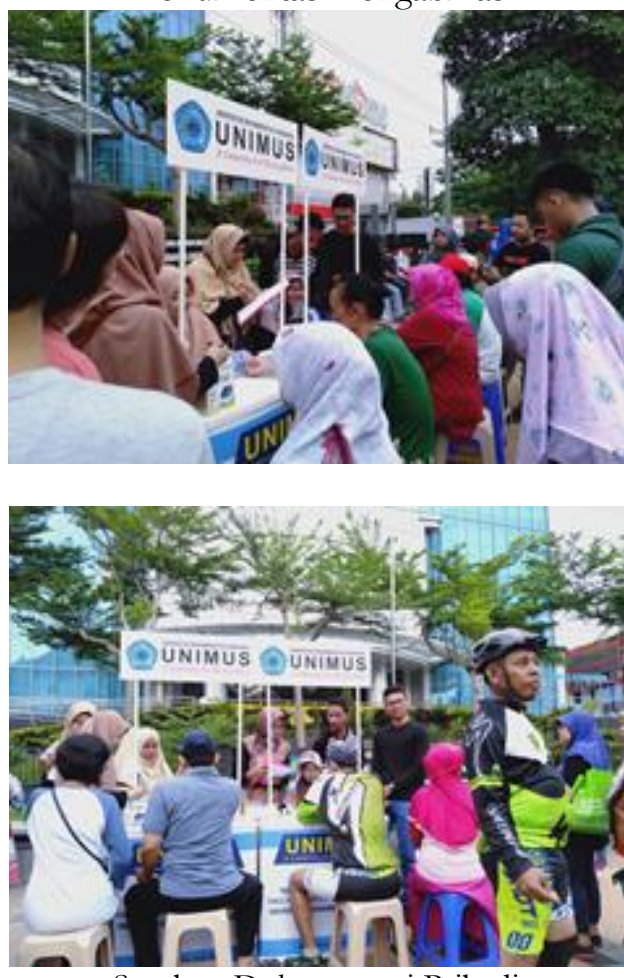

Sumber: Dokumentasi Pribadi

\section{KESIMPULAN}

Hasil pengabdian masyarakat ini berupa pemeriksaan kesehatan disimpulkan bahwa jumlah responden dengan kadar kolesterol di atas normal sebagian besar perempuan sedangkan kadar glukosa dan asam urat di atas normal sebagian besar laki-laki. Kadar rata-rata kolesterol, glukosa, dan asam urat pada laki-laki berturut-turut adalah 224,2; 123,$1 ; \quad 4,8 \mathrm{mg} / \mathrm{dL}$, sedangkan pada perempuan berturut-turut adalah 194,5; 121,2; $6 \mathrm{mg} / \mathrm{dL}$. Semakin usia bertambah, maka kadar kolesterol dan glukosa semakin meningkat dengan kadar kolesterol dari 189 menjadi $217,8 \mathrm{mg} / \mathrm{dL}$ dan kadar glukosa dari 84,4 menjadi $131,5 \mathrm{mg} / \mathrm{dL}$, sedangkan kadar asam urat cenderung menurun dari 5,4 menjadi 5,2 $\mathrm{mg} / \mathrm{dL}$. Kegiatan ini bermanfaat bagi masyarakat tentang pentingnya pemeriksaan kesehatan secara rutin sehingga dapat digunakan untuk mengecek kesehatan masyarakat.

\section{UCAPAN TERIMA KASIH}

Terima kasih disampaikan kepada Ketua Program Studi S2 Sains Laboratorium Medis (SLM) Universitas Muhammadiyah yang telah memfasilitasi kegiatan Pengabdian Masyarakat ini dan terimakasih kepada mahasiswa S2 SLM yang telah membantu kegiatan pemeriksaan kesehatan ini.

\section{DAFTAR PUSTAKA}

Andry, S. A. (2009). Analisis Faktor-Faktor Yang Mempengaruhi Kadar Asam Urat Pada Pekerja Kantor di Desa Karang Turi, Kecamatan Bumiayu, Brebes. The Soedirman Journal of Nursing, 1-6.

Kemenkes, R. I. (2013). Diabetes melitus penyebab kematian nomor 6 di dunia: kemenkes tawarkan solusi cerdik melalui posbindu. Pusat Komunikasi Publik Sekretariat Jenderal Kementerian Kesehatan RI. Jakarta.

Graha, K. C. (2010). Kolesterol. Jakarta: PT Elex Media Komputido.

International Diabetes Federation. (2015). IDF Diabetes Atlas - 7th Edition. Belgium.

Kertia, N. (2009). Asam urat. PT Mizan Publika.

Murray, D.V. (2009). Metabolisme Lipid: Pengangkutan \& Penyimpanan Lipid. dalam: Kathleen M.Bootham \& Peter A. Mayes. Biokimia Haper. Edisi 27. Jakarta: EGC; 225-233.

Nurhidayah, Astuti R, and Nurrahman. (2019). Black Rice Potential in HDL and LDL Profile in Sprague Dawlay Rat withHigh Cholerterol Diet. IOP Conference Series. Earth and Environmental Science.

Sartika, Sumangkut, Wenny S., Frenly O., (2013). Hubungan pola makan dengan kejadian penyakit diabetes militus tipe 2 di poli interna BLU.RSUP. Prof.Dr.R.D.Kandou Manado. 
Tisnadjaja D. (2006). Bebas Kolesterol dan Demam Berdarah dengan Angkak. Penebar Swadaya. Jakarta.

Widada S.T., dkk, (2016). Gambaran Perbedaan Kadar Kolesterol Total Metode HOD-PAP Sampel Serum dan Sampel Plasma EDTA. Jurnal Teknologi Laboratorium. Vol. 5, No. 1 Clinical Chemistry. 41-44.

World Helath Organization. (2016). Global Report on Diabetes.WHO Library Cataloguing-in-Publication Data 